\title{
VERTICAL PRESSURES AND COMPRESSIVE FRICTION FORCE IN A LARGE SILO
}

\author{
Marivone Z. Fank ${ }^{1 *}$, José W. B. do Nascimento², Décio L. Cardoso ${ }^{3}$, Ariadne S. Meira², \\ Fábio L. Willrich ${ }^{4}$
}

${ }^{1 *}$ Corresponding author. Universidade Tecnológica Federal do Paraná/ Pato Branco - PR, Brasil. E:mail: marivonefank@utfpr.edu.br

\section{KEYWORDS}

metal silos, grain storage, instrumentation.

\begin{abstract}
The grain flow is a dynamic phenomenon of high non-linearity, responsible for the occurrence of a high index of structural problems in silos, assuming particular interest in Brazil because the country does not have a standard of design of these structures. In order to determine the transfer of loads to the foundations, a silo in true magnitude was instrumented through pressure cells in the reinforced concrete slab of the bottom and through load cells under two of its column. The experiment was conducted during the period from December 2016 to February 2017 in Entre Rios do Oeste-PR. The profiles of vertical and the compression friction pressures were obtained during the loading, storage and unloading phases of corn grains. The vertical pressure distribution in the silo bottom was shown to be variable along its radius, in accordance with the formulation of the AS 3774 standard, an alternative to the simplified uniform distribution hypothesis prescribed by the EN 1991-4 and ANSI/ASAE EP433 standards. We also observed experimentally the non-occurrence of overpressure at the unloading of the silo under analysis. The load transfer coefficient to the column was 0.35, being that the ANSI/ASAE EP433, EN 19914 and AS 3774 standards increased this transfer by $6.57 \%, 35.91 \%$ and $75.03 \%$ respectively, reflecting the great divergence between these prescriptions.
\end{abstract}

\section{INTRODUCTION}

The complexity of grain flows in silos is still not sufficiently understood so that the sizing criteria established in the standards are capable of covering all the situations involved in the phenomenon (Palma \& Calil Júnior, 2008; Nascimento et al., 2013; Gallego et al., 2015). In addition, the data available in the literature on the interaction between the granular medium and the containment structure incorporate scale effects that are not always accurately accounted for in structural behavior models.

The large number of variables involved hampers a mathematical formalism capable of adequately expressing the phenomenon and that is applied with an acceptable margin of safety and economy (Calil Júnior et al., 2009). Many studies have been developed for the determination of pressures in silos using Janssen's theory (Lopes Neto, 2009; Nascimento \& Calil Junior 2009; Ramírez et al., 2010; Ding et al., 2011; Silva et al., 2011; Lopes Neto et al., 2014a), however, in Brazil, the calculation procedures are not standardized.
The instrumentation of real-scale structures allows the acquisition of more realistic data, by reliably measuring the interaction between the granular medium and the containment structure and enabling the evaluation of the tensions caused by the products stored in both static and dynamic conditions (Couto et al., 2012; 2013, Ruiz et al., 2012; Lopes Neto et al., 2014b, Ramírez et al., 2014, Fank et al., 2015).With reliable field results, it is possible to minimize limiting aspects to the design of these structures, contributing to a future and adequate standardization of silo designs and thus to mitigate the problems of collapses. In this study, the vertical and friction compression pressures of a silo in real scale were measured experimentally, comparing them with the theoretical values of the AS 3774, EN 1991-4 and ANSI / ASAE EP433 foreign standards.

\section{MATERIAL AND METHODS}

The analyzed silo is owned by the Cooperativa de Produtores Agrícolas, COPAGRIL, located in the municipality of Entre Rios do Oeste-PR, and was manufactured and installed by the CONSILOS industry,

\footnotetext{
${ }^{2}$ Universidade Federal de Campina Grande/ Campina Grande - PB, Brasil.

${ }^{3}$ Universidade Estadual do Oeste do Paraná/ Cascavel - PR, Brasil.

${ }^{4}$ Itaipu Binacional/ Foz do Iguaçu - PR, Brasil.

Received in: 11-7-2017

Accepted in: 6-12-2018
} 
based in the municipality of Cascavel-PR. It is part of a set of six silos, divided into two lines. Its dimensions are 18.42 $\mathrm{m}$ of internal diameter and $25.35 \mathrm{~m}$ of total height $(20.03 \mathrm{~m}$ of body and $5.32 \mathrm{~m}$ of cover), classified by EN 1991-4 (EN, 2006) and AS 3774 (1990) as being slightly slender $(1<\mathrm{hc} / \mathrm{dc}<2)$. The structure has a total volume of 5810.00 $\mathrm{m}^{3}$ and capacity to store 4357.00 tons of corn grains.

The upper and lower parts of the silo perform the loading and unloading processes respectively. It has a concentric main discharge orifice discharged by gravity measuring $42 \mathrm{~cm} \mathrm{x} 42 \mathrm{~cm}$ and four auxiliary holes of $30 \mathrm{~cm}$ x $30 \mathrm{~cm}$ distributed over the diameter to promote manual discharge of the remaining product. There is flat bottom of reinforced concrete and lateral wall of corrugated metallic sheets, manufactured with steel of high resistance (ZAR 345).

To evaluate the theoretical pressures due to the stored product, samples of corn grains were collected under the same conditions in which they were stored in the silo, obtaining the physical and flow properties, which the values are shown in Table 1.

TABLE 1. Physical and flow properties of corn grains.

\begin{tabular}{|c|c|c|c|c|c|c|c|c|c|c|c|}
\hline \multirow{2}{*}{ Product } & \multirow{2}{*}{$\begin{array}{r}\text { Cohesion } \\
\left(\mathrm{kN} \cdot \mathrm{m}^{-2}\right)\end{array}$} & \multicolumn{2}{|c|}{$\gamma\left(\mathrm{kN} \cdot \mathrm{m}^{-3}\right)$} & \multicolumn{2}{|c|}{$\phi_{\mathrm{i}}\left(^{\circ}\right)$} & \multicolumn{2}{|c|}{$\phi_{\mathrm{e}}\left({ }^{\circ}\right)$} & \multicolumn{2}{|c|}{$\phi_{\mathrm{r}}\left({ }^{\circ}\right)$} & \multicolumn{2}{|c|}{$\phi_{\mathrm{w}}\left({ }^{\circ}\right)$} \\
\hline & & Inf. & Sup. & Inf. & Sup. & Inf. & Sup. & Inf. & Sup. & Inf. & Sup. \\
\hline Corn & 1.3 & 7.50 & 7.54 & 19 & 28 & 25 & 32.5 & 25.3 & 26.6 & 9.1 & 10.8 \\
\hline
\end{tabular}

$\gamma$-specific grain weight, $\phi_{\mathrm{i}}$-angle of grain-grain friction, $\phi_{\mathrm{e}}$-effective angle of grain friction, $\phi_{\mathrm{r}}$-resting angle, $\phi_{\mathrm{w}}$-angle of grain-wall friction.

Cells with the following characteristics were used to measure the applicant efforts: hydraulic type pressure cells, EPC 3500-1-100 model from GEOKON and owned by the Federal University of Campina Grande, installed at the bottom of the silo; load cells MCC-2-60-TD10 model, from the Micro Sensores SA manufacturer, with load capacity of $600 \mathrm{kN}$ in compression, owned by the Fungeo Fundações e Geologia Ltda company, installed between the column and the stiffening ring of the silo foundation. All cells were calibrated in the Concrete Laboratory of the Itaipu Binacional Technological Park of Foz do Iguaçu - PR.

A.

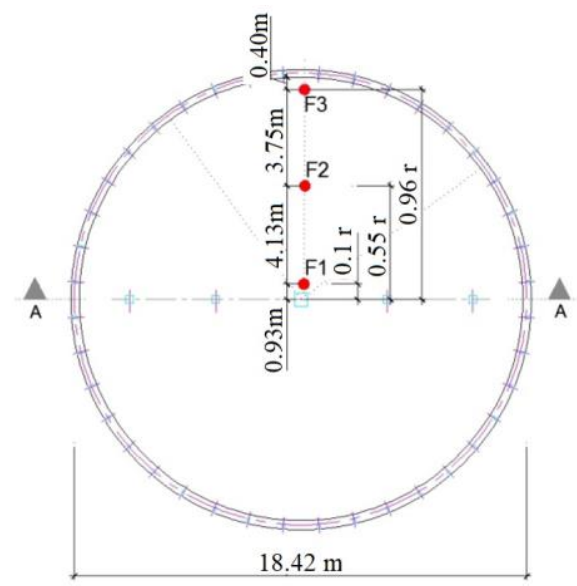

To obtain the vertical pressures, three pressure cells were installed at the bottom of the silo (F1, F2 and F3), in a single radial alignment, spaced from each other as shown in Figure 1, with the F1 and F3 cells being positioned as close as possible to the discharge orifice and silo wall, respectively, aiming with this configuration to obtain the distribution diagram of the vertical tensions along the radial direction. The distributed cells recorded the stresses derived from the weight of the material stored under gravitational field and flux.

B.

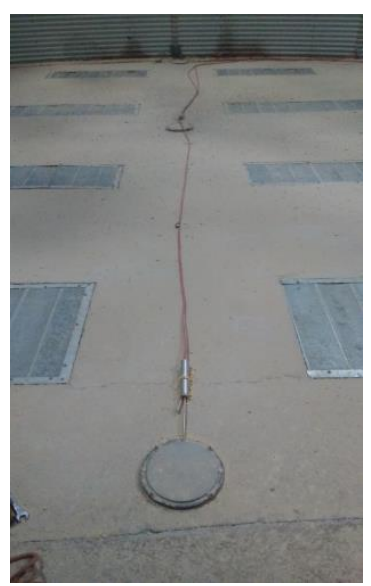

FIGURE 1. Distribution of the cells at the bottom of the silo: Plant (A); Installation (B).

The compressive forces due to the grains friction with the wall were measured through the load cells positioned under the columns ( $\mathrm{C} 1$ and $\mathrm{C} 2$ ), equidistant from each other by a $45^{\circ}$ arc, with a length of $7.23 \mathrm{~m}$, according to Figure 2 . The cells recorded the compressive force acting on the sheet metal, resulting from the load transfer from the weight of the material stored to the side walls of the silo. This compression request has vertical direction and acts from top to bottom, being transferred cumulatively to the columns from the top to the bottom of the silo where it is then registered. 
A.

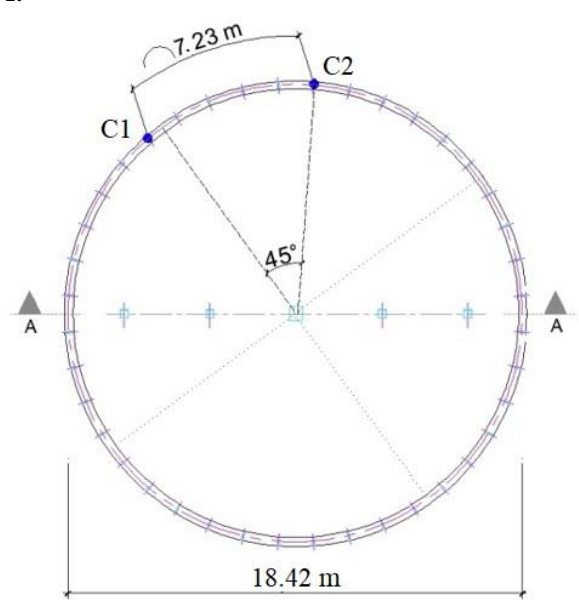

B.

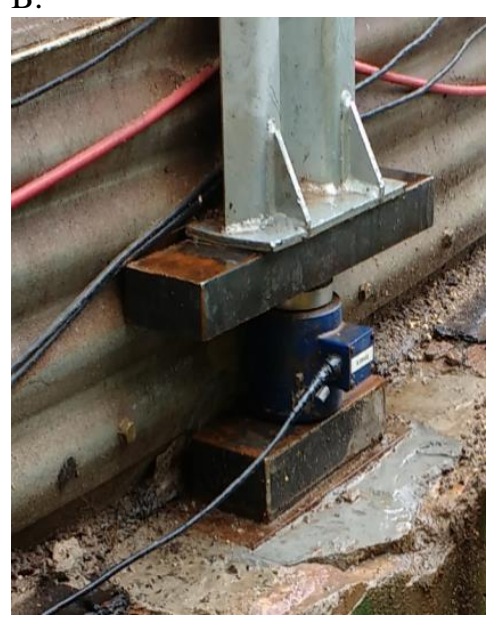

FIGURE 2. Cells in the columns: Plant (A); Installation (B).

The cells were connected through electrical cables to the Agilent TM data acquisition system, 34970A model, owned by the Universidade Tecnológica Federal do Paraná, UTFPR-Pato Branco-PR campus.

\section{RESULTS AND DISCUSSION}

The silo loading took place during eight days, storing a total of 4589.21 tons of corn grains that were stored for 32 days, with a subsequent unloading step that lasted for 18 days.

The curves of the vertical pressures acting on the bottom of the silo can be observed in Figure 3, where the curve patterns denote that the pressures are closer to the center (F1) and smaller near the silo wall (F3), in agreement with the alternative procedure of calculating the pressures recommended by the Australian standard (AS 3774, 1996).

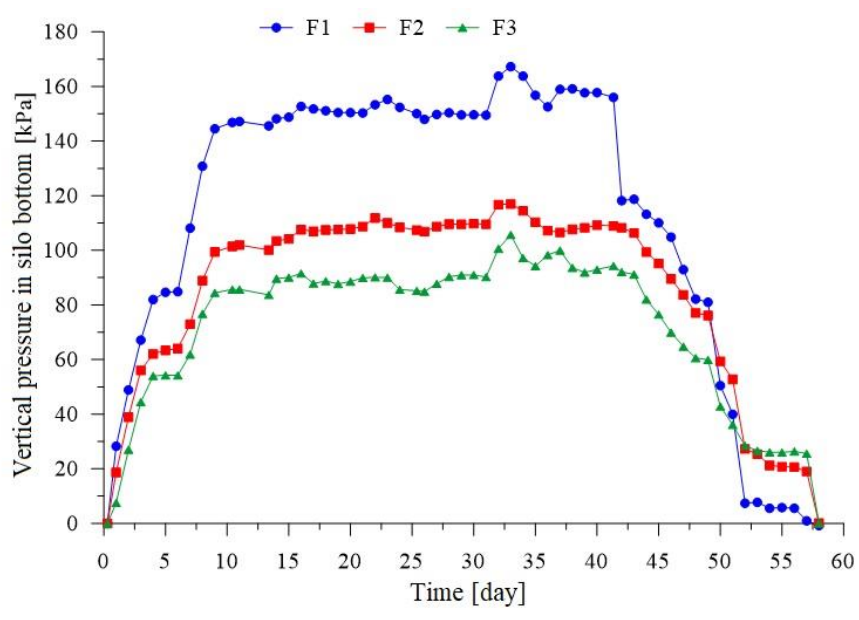

FIGURE 3. Experimental vertical pressures.

In the initial section of the loading, the pressure values recorded in the different cells diverge a little from each other, the three curves are close, being this behavior observed until the load in the silo corresponding to $63 \%$ of the maximum stored load. This means that up to that level the loads are being transferred integrally to the bottom of the silo. From this level, the curves distance themselves, showing the effect of $\mathrm{K}$ parameter, where part of the grain weight is transferred to the walls of the silo by lateral friction.

From the fourth to the sixth day, there was no loading of the silo, a fact reflected by the first plateau in the three curves. At the end of the silo loading, the F1, F2 and F3 cells recorded pressures of $130.83 \mathrm{kPa}, 88.94 \mathrm{kPa}$ and $76.77 \mathrm{kPa}$, respectively. In relation to the pressure value in the center of the silo (F1), the differences in pressures were $32.02 \%$ and $41.32 \%$ in the intermediate position (F2) and close to the wall (F3).
The storage period can be seen in the second plateau displayed by the curves in the central part of the graph, where the pressures in the cells assume invariable values with time.

At the beginning of the unloading, there is a systematic drop in the pressures. This drop is more pronounced in the F1 cell, because it is the closest to the discharge orifice, and after the complete mechanical emptying, the inversion in the position of the curves reflects the remaining grain mass in the silo that is not capable of being drained by gravity. In relation to the pressure value in the center of the silo $(\mathrm{F} 1)$, the differences in pressures were $30.20 \%$ and $39.56 \%$ in the intermediate position (F2) and close to the wall (F3), values very close to those observed in the loading.

The comparison of experimental and theoretical pressures can be evaluated by the curves shown in Figure 4 . 
A.

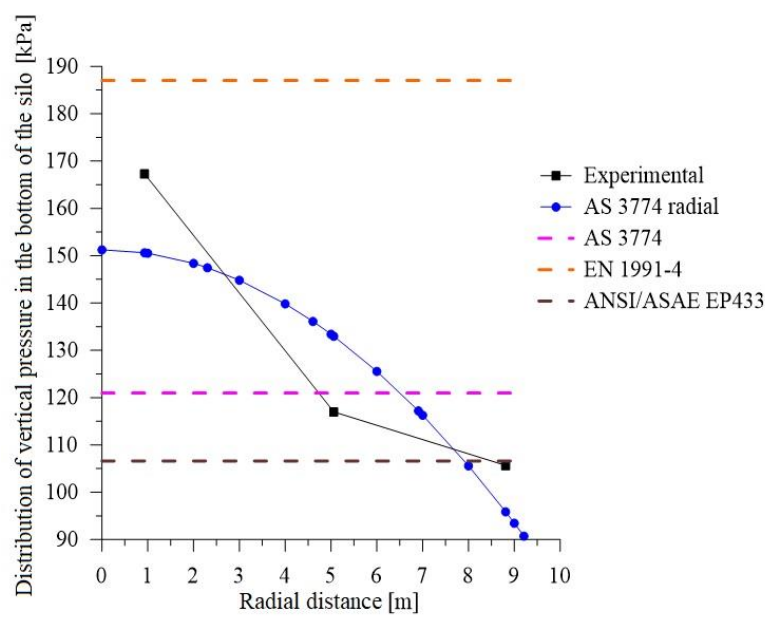

B.

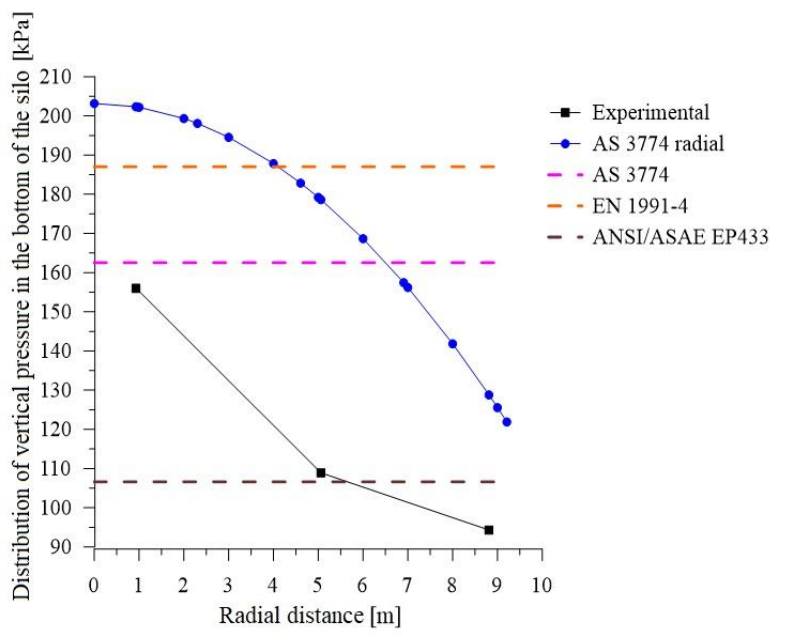

FIGURE 4. Experimental and theoretical vertical pressures: Loading (A); Unloading (B).

In the loading, the experimental vertical pressure acting at the center of the silo (F1) is greater than the uniform pressures calculated by the AS 3774 and ANSI/ASAE EP433 normative standard and lower than the EN 1991-4 theoretical standard; but the radial distribution of the pressures calculated by AS 3774 is close to the experimental curve. The maximum loading pressure calculated by the Australian standard with radial distribution is lower than the experimental pressure at $9.97 \%$, and with uniform distribution this divergence rises to $27.70 \%$. The uniform pressure value calculated by the European standard is $11.79 \%$ higher and the American standard is $36.28 \%$ lower than the experimental one.

In the unloading, the experimental pressures suffered a reduction in relation to those of the loading, evidencing the non-occurrence of overpressure. The radial distribution is displaced upwards in relation to the experimental values, due to the application of the coefficient of overpressure of the Australian standard. By standardizing the distribution of the pressures exerted on the bottom of the silo by the grain mass, the American standard leads to more realistic values, as shown by the proximity of the average pressure with the experimental value obtained at the most median point of the bottom of the silo (F2). The pressures standardized by EN
1991 and AS 3774 codes overestimate the experimental values.

Lopes Neto et al. (2014a) carried out a theoreticalexperimental analysis in a model silo with dry sand stored as a product, noting that the values of vertical pressures for the concentric unloading of the AS 3774 and ISO 11697 (1995) standards were the most adequate but $15 \%$ higher than the experimental values. When analyzing the efforts in a cylindrical silo with H/D ratio equal to 2 , Couto et al. (2013) observed that the values calculated by the recommendations of EN 1991-4 standard also overestimated the experimental results.

According to Palma \& Calil Júnior (2008), the standards mostly result in higher values due to factors such as formulation used in the calculation of the $\mathrm{K}$ factor, combinations with the physical properties to obtain the maximum loads and adoption of additional pressures in some cases.

The stresses transferred to the walls of the silo by friction are cumulative with the depth and request the columns by compression, and they were recorded in the $\mathrm{C} 1$ and C2 load cells, with the curves shown in Figure 5. The C3 cell showed malfunctioning and its data is not shown.

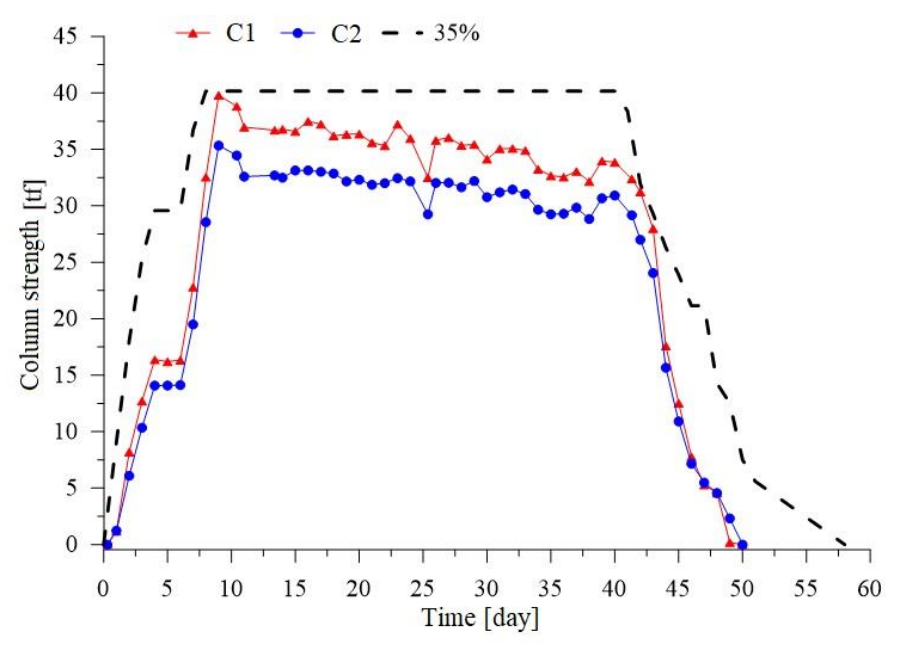

FIGURE 5. Compressive force recorded in the column in the silo loading. 
At the end of the silo loading, on the eighth day, the loads showed a difference of $13.97 \%$ between the column, due to possible asymmetry of efforts. One day after, there was a load increase in both columns corresponding to $22.27 \%$ in $\mathrm{C} 1$ cell and $22.73 \%$ in $\mathrm{C} 2$ cell, showing that the increase of load due to a possible accommodation of the grain mass was the same in both cells. At the beginning of the unloading, there was no peak pressure, evidencing the non-occurrence of overpressure; throughout the process the curves decline systematically.

In order to establish a safety criterion for estimating the effort transferred to the columns, the force envelope for a transfer coefficient of 0.35 , or $35 \%$ of the silo full capacity is also shown in the same figure. Fank et al. (2015) experimentally measured the loads transferred to the foundations by the column of a silo in real-scale during the loading of soybeans, obtaining an average transfer coefficient of 0.51 .

Table 2 shows the compressive frictional forces transferred to the columns experimentally obtained and calculated by EN 1991-4, AS 3774 and ANSI / ASAE EP433 standards. The distributed loads $q$ on the silo wall were converted into concentrated loads $Q$ taking the product $Q=q . e$, where $e$ is the spacing between columns $(1.45 \mathrm{~m})$; then the unit $(\mathrm{kN})$ was converted to $(\mathrm{tf})$.

TABLE 2. Compressive force of friction transferred to the column.

\begin{tabular}{|c|c|c|c|c|c|c|c|c|}
\hline \multirow{2}{*}{ Phase } & \multicolumn{3}{|c|}{ Distributed load q(kN.mn $)$} & \multicolumn{3}{|c|}{ Theoretical force Q(tf) } & \multicolumn{2}{|c|}{$\begin{array}{l}\text { Experimental force } \\
\mathrm{Q}(\mathrm{tf})\end{array}$} \\
\hline & EN 1991-4 & AS 3774 & $\begin{array}{c}\text { ANSI/ ASAE } \\
\text { EP433 }\end{array}$ & EN 1991-4 & AS 3774 & $\begin{array}{c}\text { ANSI/ ASAE } \\
\text { EP433 }\end{array}$ & M1 & M2 \\
\hline Load & 352.91 & 454.57 & 242.64 & 51.06 & 65.76 & 35.10 & 39.80 & 35.34 \\
\hline Unload & 358.88 & 545.48 & 242.64 & 51.92 & 78.91 & 35.10 & 32.39 & 29.18 \\
\hline
\end{tabular}

At the loading, the EN 1991-4 and AS 3774 standards overestimated the compressive friction force, which were $35.91 \%$ and $75.03 \%$, respectively, compared to the experimental average value $(37.57 \mathrm{tf})$, while the ANSI/ASAE EP433 standard underestimated the average experimental value by only $6.57 \%$. Therefore, the American standard provided more realistic values for the compressive frictional force.

At the unloading, the EN 1991-4 and AS 3774 standards increased the compressive friction force by $68.63 \%$, and $156.28 \%$, respectively, in relation to the average experimental force $(30.79 \mathrm{tf})$, while the ANSI/ASAE EP433 standard increased this compressive friction force by only $14.02 \%$.

\section{CONCLUSIONS}

1. The EN 1991-4 standard overestimated the vertical pressures in the silo while the ANSI/ASAE EP433 standard underestimated them, both of which do not predict dynamic effect due to unloading, which was also verified by the instrumentation. The experimental results showed a radial distribution of the pressures acting on the bottom of the silo, in accordance with the alternative procedure of AS 3774 for the loading; for the unloading, the code prescribes application of coefficient of overpressure, which overestimated the experimental values.

2. The ANSI/ASAE EP433 (2002), EN 1991-4 (2006) and AS 3774 (1996) standards increase the average values of the loads transferred to the silo columns by $6.57 \%$, $35.91 \%$ and $75.03 \%$, respectively. Therefore, the American code restores the values more compatible with the reality in relation to the evaluation of the frictional compressive forces.

3. The criterion of shaping the experimental data to meet the safety and economy requirements showed that the coefficient 0.35 is the most appropriate in evaluating the efforts transferred to the foundations of the silo.

\section{REFERENCES}

ASAE - American Society of Agricultural Engineers (2002) Loads exerted by free-flowing grain on bins. ANSI/ASAE EP433 DEC 1988 (R2001). St Joseph.

AS 3774. Loads on bulk containers. Sydney: Australian Standard, 1996. 78p.

Calil Júnior C, Palma G, Cheung AB (2009) Failure Modes of cylindrical corrugated steel silos in Brasil. Bulk solids handling 29:346-349.

Couto A, Ruiz A, Aguado PJ (2012) Design and instrumentation of a mid-size test station for measuring static and dynamic pressures in silos under different conditions - Part I: Description. Computers and Electronics in Agriculture 85:164-173. DOI: https://dx.doi.org/10.1016/j.compag.2012.04.009

Couto A, Ruiz A, Herraez L, Moran J, Aguado PJ (2013) Measuring pressures in a slender cylindrical silo for storing maize. Filling, static state and discharge with different material flow rates and comparison with Eurocode 1 part 4. Computers and Electronics in Agriculture 96:40-56. DOI:

https://dx.doi.org/10.1016/j.compag.2013.04.011

Ding S, Rotter JM, Ooi JY, Enstad G (2011) Development of normal pressure and frictional traction along the walls of a steep conical hopper during filling. Thin-Walled Structures 49:1246-1250. DOI: https://dx.doi.org/10.1016/j.tws.2011.05.010

European Committee for Normalisation (2006) EN 19914: EUROCODE 1. Actions on structures - Part 4: Silos and tanks, 122p.

Fank MZ, Christ D, Cardoso DL, Willrich FL, Lorenzi V (2015) Coeficiente de transferência de carga nas fundações de silos verticais cilíndricos. Revista Brasileira de Engenharia Agrícola e Ambiental 19(9):887-891. DOI: http://dx.doi.org/10.1590/1807-1929/agriambi.v19n9p887891 
Gallego E, Ruiz A, Aguado PJ (2015) Simulation of silo filling and discharge using ANSYS and comparison with experimental data. Computers and Electronics in Agriculture 118:281-289. DOI:

https://dx.doi.org/10.1016/j.compag.2015.09.014

ISO 11697. Bases for design of structures: loads due to bulk materials. Switzerland: International Organization for Standardization. 1995. 16p.

Lopes Neto JP (2009) Análise teórico-experimental das forças verticais e de atrito em silos cilíndricos. Tese Doutorado, Universidade Federal de Campina Grande.

Lopes Neto JP, Nascimento JWB do, Fank MZ (2014a) Forças verticais e de atrito em silos cilíndricos com fundo plano. Revista Brasileira de Engenharia Agrícola e Ambiental 18(6):652-657. DOI: http://dx.doi.org/10.1590/S1415-43662014000600013

Lopes Neto JP, Nascimento JWB do, Silva RC (2014b) Forças de atrito em silos verticais de paredes lisas em diferentes relações altura/diâmetro. Engenharia Agrícola 34(1):8-17. DOI: http://dx.doi.org/10.1590/S010069162014000100002

Nascimento FC, Calil Junior C (2009) A relação entre as pressões horizontais e verticais em silos elevados: o parâmetro K. Cadernos de Engenharia de Estruturas 11(52):17-37.

Nascimento WB do, Lopes Neto JP, Montross MD (2013) Horizontal pressures in cylindrical metal silos and comparison with different international standards. Engenharia Agrícola 33(4):601-611. DOI: http://dx.doi.org/10.1590/S0100-69162013000400002
Palma G, Calil Júnior C (2008) Pressões e fluxo em silos esbeltos $(\mathrm{H} / \mathrm{D} \geq 1,5)$. Cadernos de Engenharia de Estruturas 10(42):129-150.

Ramírez A, Nielsen J, Ayuga F (2010) On the use of platetype normal pressure cells in silos. Part 2: validation for pressure measurements. Computers and Electronics in Agriculture 71:64-70. DOI:

https://dx.doi.org/10.1016/j.compag.2009.12.005

Ramírez A, Gallego E, Fuentes JM, González C, Porras CJ, Ayuga F (2014) Full-scale tests to measure stresses and vertical displacements in an 18.34 m-diameter agricultural steel silo roof. Computers and Electronics in Agriculture 106:56-65. DOI:

https://dx.doi.org/10.1016/j.compag.2014.05.008

Ruiz A, Couto A, Aguado PJ (2012) Design and instrumentation of a mid-size test station for measuring static and dynamic pressures in silos under different conditions - Part II: Construction and validation. Computers and Electronics in Agriculture 85:174-187. DOI: https://dx.doi.org/10.1016/j.compag.2012.04.008

Silva FS da, Côrrea PC, Calil Junior C, Gomes FC (2011) Análise dos coeficientes de atrito estático e dinâmico de grãos de café com pergaminho, determinados em diferentes equipamentos, teores de água e materiais de parede. Revista Brasileira de Produtos Agroindustriais 13(2):143-156. DOI: https://dx.doi.org/10.15871/15178595/rbpa.v13n2p143-156 